\title{
Correction to: From patient-centred ethics to the ethics of a pandemic
}

\section{Andreas K. Demetriades ${ }^{1}$}

Published online: 11 February 2021

(C) Springer-Verlag GmbH Austria, part of Springer Nature 2021

\section{Correction to: Acta Neurochirurgica} https://doi.org/10.1007/s00701-020-04666-2

The correct doi of reference 8 should be the below:

8. Eijkholt M, Hulsbergen A, Muskens I et al (2021) Should neurosurgeons continue to work in the absence of personal protective equipment during the COVID-19 era? Acta Neurochir. https://doi.org/10.1007/s00701-021-04703-8.

The original article has been corrected.

Publisher's note Springer Nature remains neutral with regard to jurisdictional claims in published maps and institutional affiliations.

The online version of the original article can be found at https://oi.org/ 10.1007/s00701-020-04666-2

$\triangle$ Andreas K. Demetriades

andreas.demetriades@gmail.com

1 Department of Neurosurgery, Royal Infirmary of Edinburgh, Little France, Edinburgh EH16 4SA, UK 